\title{
Household water supply vulnerability in low income communities in Ghana: Experiences from Aboabo in the Kumasi Metropolitan Area
}

\author{
Ebenezer Owusu-Sekyere ${ }^{1}$, Arkum Thaddeus Aasoglenang ${ }^{2}$, Samuel Z. Bonye ${ }^{2}$ \\ ${ }^{1}$ Department of Development Studies, University for Development Studies WA, Ghana \\ ${ }^{2}$ Department of Community Development, University for Development Studies, Wa, Ghana
}

Email address:

oseturbo@yahoo.com (E. Owusu-Sekyere)

To cite this article:

Ebenezer Owusu-Sekyere, Arkum Thaddeus Aasoglenang, Samuel Z. Bonye. Household Water Supply Vulnerability in Low Income Communities in Ghana: Experiences from Aboabo in the Kumasi Metropolitan Area. International Journal of Environmental Protection and Policy. Vol. 2, No. 1, 2014, pp. 9-18. doi: 10.11648/j.ijepp.20140201.12

\begin{abstract}
The process of urbanization holds great promise for economic and social progress of a nation. On the other hand this process is confronted with a lot of challenges. One such challenge is the increasing vulnerability to quality water supply among households in low income urban communities. In Ghana, urban households do not have water flowing regularly through their taps from the Ghana Water Company Limited (GWCL) and therefore have to supplement their limited supply with water from sources such as Streams/Rivers and Wells. Indeed, whereas the quantity of available water is decreasing, the quality is also compromised mainly due to high population growth accompanied by low investments by the state. This research examines the extent of water supply vulnerability among households at Aboabo, a low income community in the Kumasi Metropolitan Area. Using both quantitative and qualitative approaches, the research revealed that water from source other than GWCL was highly polluted. This is evidenced from the higher counts of faecal coliforms and E. coli in the water bodies. Again, the research showed higher concentrations of physicochemical properties which were above the WHO standard for safe drinking water. The concentrations of microbiological and physiochemical properties in the water sources had implications on human health as most of the diseases reported were water related. The paper argues that Kumasi is well endowed with water resources, but the amount of water available for distribution within the city is far from uniform with the low income communities seriously underserved. The paper concludes that if this situation is not addressed with specific policy interventions, the consequence could be disastrous.
\end{abstract}

Keywords: Vulnerability, Water Quality, Pollution, Leachate, Health Effect

\section{Introduction}

Whilst the world's urbanization trend tends to experience recession in most developed countries, the trend in Sub-Saharan Africa on the contrary, is rapidly experiencing an unprecedented growth (Mcgranahan et al., 1996). It is estimated that by 2025 , more than half of the Sub-Saharan African population will be living in towns and cities. The Sub-region's population growth rate, which stands at 2.6 percent per annum, ranks the highest in the world and therefore places additional strain on all systems.

The urbanization process has many impacts that can be classified into three major groups (Mwangi, 2003). One group includes impacts on the physical form and sociocultural character of urban areas. These affect, for example, the growth of mega cities, the fragmentation of urban areas, the formation of national and international urban systems and diversification of social behaviors and lifestyles within cities. A second group includes impacts that are notable for their negative effects. These are revealed as growth of insecurity in urban areas, lack of affordable housing or secure tenure, increasing social exclusion, traffic congestion, environmental pollution, shrinkage of the formal economy and crisis in urban management. There is a third group of impact that seems to be mainly positive. These include the spread of urban democracy and increase in urban productivity, particularly in the informal sector (ibid). 
This study however focuses on the negative impacts of urbanization and how it affects social service provision including water supply. One of the grand challenges of humanity in recent times is the increasing vulnerability to natural resources including water pollution (McGregor et al 2000). Throughout history and in all societies water has occupied a central place in human endeavors. This stems from the fact that it is an inalienable part of the total human existence (Bacho, 2001). The World Health Organization in 2008 estimated that approximately 1.3 billion people in the developing world lacked access to adequate quantities of clean water, and nearly 3 billion people were without adequate means of disposing of their faeces. WHO again estimates that about 10,000 people die every day from water and sanitation related diseases, and thousands more suffer from a range of debilitating illnesses (WHO, 2005). In all these the impact falls primarily on the poor especially those living in shacks and slums.

Badly served by the formal sector, the poor make their own, often inadequate arrangements to meet their water needs. This is typified by the long distances they have to trek to get this precious commodity. In the event of acute supplies they end up paying high prices to water vendors for very small quantities of water. The clear need for basic water and sanitation services for the poor assumes even greater significance when the linkages with other dimensions of poverty are considered. Water and sanitation related sicknesses put severe burdens on health services and keep children out of school.

The provision of water and sanitation services in deprived urban settlements is a challenge faced by many countries in Sub-Sahara Africa (WHO, 2005). The growth of towns and cities together with the rapid increase in urban populations has meant that low income and unplanned settlements are growing much faster than formal and planned settlements. Low levels of services such as water supply and sanitation are the result. The lack of these services threatens not only the health and the environment of people in low income and unplanned areas, but also that of people living in formal and planned areas (see Kanton et al., 2010). According to Pinderhughes (2004) cities are the places where most of the human population now resides and where most of the resource consumption and waste generation takes place, Kumasi is no exception to this phenomenon.

The Kumasi Metropolis, like cities in most developing nations, is experiencing increasing and unprecedented population growth rates. A city which had a population of 346,336 in 1970 and 487,504 in 1984 recorded over $2,022,919$ people in 2010 , representing an annual growth rate of 5.4 per cent (KMA, 2010), which is one of the highest recorded in the sub-region. This phenomenal growth of the urban population has exacerbated efforts to secure environmental health. The metropolitan authorities have not yet ensured that the rapid urban growth is accompanied by investments in environmental services, especially in the comparatively poorer communities. The problem is particularly severe in the numerous under serviced and unplanned low income communities within the metropolis. About one-third of the population currently lives in these underserved communities which include Aboabo, Oforikrom, Ayigya and Asewase to mention but a few where households are economically deprived and socially constrained (KMA, 2010). Unless authorities prepare the city to meet some of their environmental challenges, the social consequences could be detrimental.

According to WHO, Ghana has currently exceeded its 2015 target of 78 percent coverage for use of improved drinking water by six percent. However, a significant proportion totaling about 3.5 million many of whom are in low income communities in Ghanaian cities still do not have improved sources of drinking water (Daily Graphic, 2013). One of such communities is Aboabo, a low income community in the Kumasi Metropolis. The vigorous commercial activities along River Aboabo also generate both liquid and solid wastes which are directly dumped into the river obstructing flow and causing pollution. Additionally, encroached houses empty their domestic sewerage in to the River without any initial treatment.

The problem of water supply is complicated by the activities of street vendors along the Kumasi-Accra highway generating thousands of tons of waste of which a significant proportion is washed into the River during rainfall. The location of lorry parks and Gas stations in close proximity to River Aboabo also poses threat of chemical pollution due to the likely seepage of petroleum products into the water bodies. This problem is compounded by the presence of wooden slum houses constructed along the course of the River thus restricting the maintenance of safe minimum standards of environmental quality. The Aboabo community is endowed with a lot of water resources that could serve as alternative sources of drinking water to augment the supplies from the Ghana Water Company Limited, but the extent of pollution from the environment has always questioned the wholesomeness of such water sources.. Pollution of the water bodies in the area has been persistent because controls of discharge from the environment are difficult to enforce. High quantities of these pollutants will certainly have negative health implications on residents when utilized.

It is therefore imperative to assess the quality of water from some of these alternative sources. This is a crosssectional study that attempts to examine the extent of vulnerability to limited access to clean and safe water at Aboabo. The study is organized in five main parts. After the introductory paragraphs, the subsequent section outlines the conceptual framing, which draws on the vulnerability assessment framework. The research methodology is giving a critical consideration in the third section while the fourth section provides the results and analysis of the study. The final section is devoted to conclusions and policy recommendations. 


\subsection{Vulnerability Assessment Model}

According to Giupponi et al.( 2012), the term 'vulnerability' originally had has its roots in geography and natural hazards research but this term is now being used in a variety of other research discipline such as ecology, public health, poverty and development, livelihood and food security, sustainability science, land use change, and climate change impacts and adaptation. Each of these disciplines defines 'vulnerability' to suit their interest. Birkman (2006) has provided an overview of the evolution of the different spheres of widening vulnerability concepts evolving from intrinsic risk factors to a much broader multidimensional concept, encompassing physical, social, economic, environmental and institutional features. Within such broader vision, different schools of thought have emerged. These include the Climate Change Adaptation (CCA) community (Füssel 2006); the Disaster Risk Reduction (DRR) community (Bogardi 2004); the Global Environmental Change (GEC) and Sustainability Science Community (Turner et al. 2003). Each of these schools therefore defines and assesses vulnerability from their perspective. Therefore, these conceptual approaches can lead to the formulation of diverse policies. Following from this, Eakin et al. (2009) suggest that the trade-off between alternative approaches should always be made explicit. According to Torry (1978), the DRR school of thought which was established in the 1970 s, views disasters as having socio-economic and political origins. Later, it considered the wider social, political, environmental and economic dimensions of hazards (ibid). The strategies for DRR include hazard, vulnerability and coping capacity assessments, as well as understanding the community's ability to reduce its own risks Wisner et al. (2004). Mercer, (2010) suggests that although the DRR and CCA communities have both been engaged in reducing socioeconomic vulnerability to natural hazards, they have given different definitions and conceptualizations of the same terminology. For example, a 2004 document from the International Strategy for Disaster Reduction (ISDR) shows that the conceptualization of vulnerability by the DRR community is different from the conceptualization by the CCA community (Parry et al. 2007). The International Strategy for Disaster Reduction (ISDR) defines vulnerability as the conditions determined by physical, social, economic and environmental factors or processes, which increase the susceptibility of a community to the impact of hazards. In the words of Parry et al, (ibid), Vulnerability is a function of the character, magnitude, and rate at which a system is exposed, its sensitivity, and its adaptive capacity". Several indices have been proposed in the field of water supply quality and environmental studies with the aim of providing assessment for water quality vulnerability. Vulnerability assessment of water quality very often, incorporates only physical components consisting, of water scarcity calculations using the water scarcity index which according to Vörösmarty et al. (2000) can be defined as the ratio of water demanded to the supplied volumes. However, annual level assessment of water scarcity does not incorporate the fact of inter-annual seasonality. In addition to this, the water scarcity calculation considers water only as a 'physical resource', rather than as one component of a much broader and more complex water resource systems. With a more holistic system view of water quality, several recent studies (Hamouda et al. 2009) have conducted vulnerability assessment and proposed other concise indices which takes account other social indices.

From this argument, some conceptual gaps in the application of the vulnerability concept come up. Firstly, the lack of consideration of futuristic aspects is one of the main shortcomings of vulnerability assessment in general, and vulnerability assessment of water quality in particular. Secondly, vulnerability assessment of water quality has tended to concentrate much on the physical aspect of water resources without paying much attention to the concept of social-ecological system. Thirdly, vulnerability assessment of water quality is not mostly accomplished through involving stakeholders. These short comings in the use of the vulnerability framework in water quality management have called for a paradigm shift in theoretical approach to water resource management. Alternatively, emphasis has now shifted to the concept of Integrated Water Resources Management (IWRM) as espouse by the United Nations World Water Development Report which considers how individuals, organizations and society can be considered as a social system which is nested within an ecological system (Simonovic 2009). Therefore, it is the complex interactions of the social-ecological system that make decision making more and more difficult in the WRSM (UNESCO 2009). Integrated Water Resources Management (IWRM) is such an approach that has been widely accepted internationally as the way forward for efficient and equitable management of water resources.

The Global Water Partnership defined "IWRM as a process, which promotes the coordinated development and management of water, land and related resources, in order to maximize the resultant economic and social welfare in an equitable manner without compromising the sustainability of vital ecosystem" (UN-Water 2008). According to this approach, water managers address the demands of water users to meet the life-sustaining requirements of people (social dimension) and the needs of other species (ecological dimension) and to create and support livelihoods, by implementing an iterative and adaptive participatory process. Although IWRM is considered by a majority of scientists and experts as useful theoretical framework, it is now openly debated whether it is truly effective in terms of operational implementation. The IWRM approach can nevertheless provide an opportunity for the development of a method for vulnerability assessment.

The subsequent discussions will explore how the Aboabo community is vulnerable to poor quality of water sources and how it impacts on their health. 


\section{Research Methodology}

\subsection{Study Area}

Aboabo is a Zongo community in the Asewase sub metro of the KMA. The people of Aboabo were resettled from old Zongo (around Roman Hill). The community falls within the wet sub - equatorial climate type. It has an average humidity of about 84.16 per cent at 0900 GMT and 60 per cent at 1500 GMT. The average minimum temperature is about $21.5^{\circ} \mathrm{C}$ and a maximum average temperature of $30.7^{\circ} \mathrm{C}$. Islam is the dominant religion.

The condition of the built-up area is characterized by poor drainage system, indiscriminate garbage disposal, and improper control of livestock, poor toilet facilities and unauthorized building extension. The erosion in the area is at an advance stage due to the poor drainage system and the bad condition of the ancillary roads. There is an open solid waste dumpsite which originally started as a collection point, but the volume of waste it receives and the inability of city authorities to organize regular collection has turned the facility to an open dumpsite. It is located on the fringes of River Aboabo which flows to join the Subin River, the largest river and the alternative source of drinking water to many, a resident in the Metropolis.

River Aboabo is about $10.6 \mathrm{~km}$ long and has its source at the northern boundary of the city at Old Tafo. At varied points, the River yields an average speed of $0.87 \mathrm{~m} / \mathrm{s}$ (Omane, 2002). An important tributary is the Dichem, which has its source at Odumasi. Apart from few road culverts, this River is undeveloped and overflows its banks at several points. The population on the River basin is estimated that about 449692 persons live in the basin approximating a quarter of the total population of the Kumasi metropolis (Danquah et al., 2011).

There are many buildings and structures very close to the river into which both solid and liquid wastes are directly discharged. Majority of the buildings are temporary structures such as kiosk and containers. In Aboabo a little over $38 \%$ of the residents use public toilets or have such facilities in their homes. As much as $50 \%$ of residents along the river do not have toilet facilities in their houses, thus residents especially children defecate around (free range), into the river as well as on the dumpsite. The river is often choked with refuse and stagnant water, posing serious health threat. The lack of enforcement of policies and legal instruments on regional and physical planning further contributes to the deterioration of living condition in the face of uncontrolled urban growth.

\subsection{Data Collection}

This cross-sectional study was conducted during the dry season of November 2012 -February 2013. This is the period where there is wide spread water shortage and the period that the Ghana Water Company is unable to supply regular pipe borne water to most households in the metropolis and therefore households supplement their irregular water supply with water from Rivers and Wells. The mixed method approach of research was used.

As a starter, we reviewed extensive literature on access to water in the study area. We also conducted in-depth interviews with officials from the Environmental Protection Agency (EPA), Ghana Water Company Limited (GWCL), Regional Coordinating Council (RCC), Kumasi Metropolitan Assembly (KMA) and Community Water and Sanitation Agency. The interviews covered themes on their role in water supply and sanitation issues in the KMA.

Secondly, we held three focus group discussions with residents. This approach is deemed appropriate when the object of the research is to explore reactions of a group or community in response to some commonly experienced aspects of their environment (Tsiboe, 2004). Through such interactive discourses, participants were able to offer insights on the perspective of the community, revealing clues to the social contexts that shape their opinions (Saleh 2002). Each focus group had seven participants composed of men and women. Issues discussed during the FGDs included the question of access to water, sanitation, water quality, and their knowledge on the possible link between poor water quality and health. All the proceedings, which were mainly in the local language, were recorded and later transcribed, analyzed and organized around the key themes.

In the third methodological approach, we conducted water quality test on the various water sources available to the community-River Aboabo (two sample sites) and two wells dug in the community.

The parameters that were selected for this study included faecal coliforms, E.coli (bacteriological analyses), $\mathrm{p}^{\mathrm{H}}$, Biochemical Oxygen Demand (BOD), Chemical Oxygen Demand (COD), Dissolved Oxygen (DO), Chloride, Total Dissolved Salt (TDS), and Sulphate (physicochemical characteristics) and Lead Nickel Copper Cadmium Chromium (Trace metals).

At each sampling site, a clean 1-litre polyethylene sample bottle was filled with water. This was subsequently used in the laboratory analysis. For dissolved oxygen (DO) determinations, separate samples were collected into 300 $\mathrm{ml}$ plain glass bottles and the DO fixed using the azide modification of Winkler's method. Samples for biological oxygen demand (BOD) were collected into dark glass bottles for incubation and subsequent DO determination.

Samples for bacteriological analyses were collected into sterilized plain glass bottles. The water samples were kept at $4{ }^{\circ} \mathrm{C}$ and transported to the laboratory for analysis. Sampling bottles were appropriately labeled and record was made of each of them. The samples were kept in a refrigerator to avoid external contamination or deterioration, until the time of the analysis. A $100 \mathrm{ml}$ volume of a water sample was drawn through a membrane filter $(0.45 \mu \mathrm{m}$ pore size $)$ through the use of a vacuum pump. The filter was placed on a petri dish containing $\mathrm{M}$ FC agar and incubated for 24 hours at $44.5{ }^{\circ} \mathrm{C}$ (112.1 degrees F). All the analyses were based on standard methods as appropriate to each water quality parameter, as 
prescribed in the World health Organization guidlines. Conductivity was measured with Cybersan 510 conductivity meter, trace metals by atomic absorption spectrophotometer, sulphate by the turbidimetric method, and chloride by argentometric titration. Faecal coliforms were determined by membrane filtration method using $\mathrm{M}$ Endo-Agar Les (Difco) at $37{ }^{\circ} \mathrm{C}$ and on MFC Agar at $44{ }^{\circ} \mathrm{C}$, respectively. With the analysis, the value of each parameter was compared to the Ghana Water Company standards.

All tests were conducted at the Ashanti Regional Laboratory of the Ghana Water Company Limited in Kumasi.

\section{Results and Discussions}

\subsection{Household Access to Water Supply at Aboabo}

Whilst water is a basic necessity of life, the nature of its access and how it is handled can have profound effects on human health. There are a number of factors influencing households' access to safe water supplies. These include issues such as the distance between the dwelling and the water source and how the water is transported to the house. In-house piping simplifies all household water issues. Access to piped water inside the house is closely related to planning, but also to household wealth.

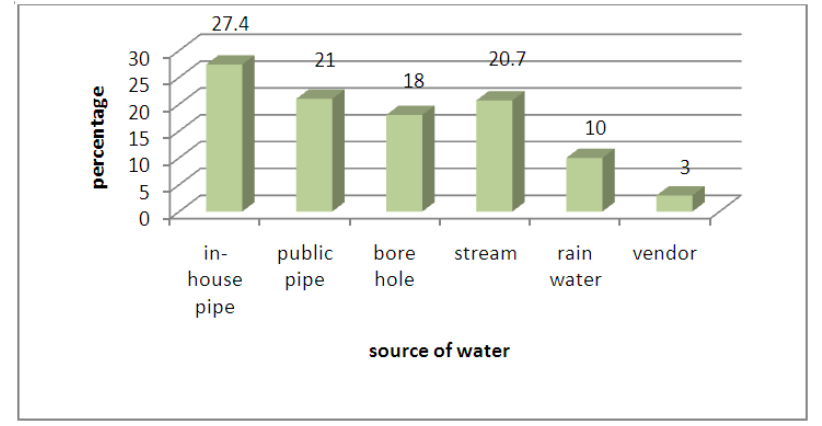

Figure 1. Household Access to Water Supply at Aboabo (GWCL 2009)

Figure 1 shows that with the exception of $27.4 \%$ who relied on in-house pipe supplied by the Ghana water company, the rest of the households supplement their limited potable water utilization with other sources such as streams, rainwater or water from vendors. The poor quality of water from these sources may have dire consequences on human health.

\subsection{Quality of Water Sources at Aboabo}

The aim of the water quality analysis was to collect baseline water quality data on the various sources of household water supply in order to ascertain the underlying factors responsible for water contamination problems and evaluate their health implications on the population. The scope of work that was covered included bacteriological analysis-faecal coliforms and E. coli contamination. These parameters were of priority because of its immediate link to human health. Physio-chemical parameters of the water sources were also determined because their effects are linked to cancers and other chronic long-term illnesses (often long time of consumption contaminated water required).

\subsection{Bacteriological Analysis}

Faecal coliform and E. coli contamination were wide spread, see table 1 .

Table 1. Results of Water Quality Tests

\begin{tabular}{lcc}
\hline Water Sources & Faecal Coliform & E. Coli \\
\hline River Aboabo & & \\
S 1 & 17.1 & 6.9 \\
S 2 & 96.0 & 7.1 \\
Well water & & \\
well 1 & 3.8 & 0.3 \\
well 2 & 4.1 & 0.2 \\
WHO Guideline Value mg/l & $0 / 100(3 / 100-$ & $0 / 100$ \\
\hline
\end{tabular}

S 1(Upstream-Cenema)

S 2 (Downstream-Alonga Junction)

Well 1(Near Aboabo Mosque)

Well 2(Near WEAC)

The higher counts of faecal coliforms and E.coli in water sources in the study area was attributed to the presence of the solid waste dump and the insanitary conditions which produces leachate that have the potential of polluting the environment and the water table. In an interview with the metropolitan sanitation officer, he had this to say "Leachates have been implicated as environmental pollutant such as soil, surface water and groundwater pollution around the Aboabi watershed. The leachate from the open dump site is highly concentrated that a very small amount of is able to pollute large amounts of groundwater including the Wells thus rendering it unsuitable for use for domestic water supply. In addition to potential carcinogens and highly toxic chemicals, leachate contains a variety of conventional pollutants that render a leachatecontaminated groundwater unusable or highly undesirable due to tastes and odour, and this could have implications on residence". He continued that in the period of heavy rainfall the microbial load of running water from the environment may suddenly increase substantially and reach water sources quickly.

Although the streams have an appreciable selfpurification capacity, the capacity is strained by persistent pollution overloads. Self-purification is the ability of water bodies (streams) to reduce or eliminate the undesirable contaminants (Mehrdadi et al. 2006). The pollution plight of the water sources was because they are flanked by 
expanding human settlements, institutional and socioeconomic activities and poor solid waste management activities. Given the highly concentrated nature of leachate from the waste dumpsite and the fact the chemical is not regulated, one can assumed that the leachate-contaminated groundwater does not meet all drinking water maximum contaminant levels which means that the water should be properly treated before it can be considered safe to consume. Furthermore, once the groundwater is contaminated, the associated aquifer cannot be cleansed so as to render the water reliable for consumption; the aquifer must be abandoned for future use as a domestic water supply source during drought periods.

Faecal coliforms, which are indicators of faecal contamination, was above WHO guidelines. High level of faecal coliforms and E.coli counts do not make the water suitable for domestic use without treatment. For agriculture purposes, vegetables watered with these sources may also be contaminated. The high faecal coliforms counts in River Aboabo are signs of biological contamination by pathogens. Again, the high faecal coliforms observed make the river unsuitable for swimming, boating and fishing (WHO, 2004). It also indicates significant health risk to humans and other aquatic animals. Furthermore, the high E. coli counts detected in the river indicated heavy pollution. The results further suggest the general sanitary qualities of the water in the catchment area. For water to be considered as no risk to human health, the faecal coliform and E. coli counts $/ 100 \mathrm{~mL}$ should be zero (ibid). The poor microbial quality might be due to contamination caused by human activities and the livestock that graze on the banks of the water bodies.

The higher counts of faecal coliforms and E.coli in Wells located in the study area can be attributed to the absence of natural soil protection and filtration functions and the possibly short distances between the input of contamination and water extraction. Especially, in the case of heavy rainfall, the microbial load of running waters may suddenly increase substantially and reach the Wells quickly. Most catchment areas of the water sources are heavily contaminated due to their closeness to the open dumpsites. Again the catchment areas have forest cover and are heavily affected by agriculture and settlements, providing ideal conditions for contamination, particularly during heavy rainfall. Another source of faecal contamination arises from the relatively high density of livestock, including Ducks, Sheep and Goats. Other factors influencing the quality of water from the Wells are human activities such as bathing and washing of clothes and vehicles close to the water as well as the use of multiple containers to draw water. Human faecal pollution in the study area can also be attributed to outdoor defecation, chamber pots contents and septic overflows that are channeled to the river by residents. Human faecal pollution constitutes the greatest public health threat because humans are reservoirs for pathogens including bacterial, protozoa and viruses (Peters et al., 2000). Animal faecal waste is also a serious health concern as they may contain pathogens.

Faecal coliforms have been shown to represent 93-99\% of coliform bacteria in faeces from humans, poultry, cats, dogs and rodents (WRC, 2003). The variations among the sampling sites (between upstream and downstream) deserve a significant note. Faecal coliform counts ranged from a minimum of $17.1 \mathrm{cfc} / 100 \mathrm{ml}$ at upstream to a maximum of $96.0 \mathrm{cfc} / 100 \mathrm{ml}$ at downstream. This was expected as the level of pollution from faecal coliforms increase along the stretch of the river as a result of indiscriminate dumping of solid waste and defecation. The counts of faecal coliforms in almost all occasions of sampling sites indicate significant and increasing risk of infectious disease transmission. As faecal coliform levels increase beyond $20 \mathrm{cfc} / 100 \mathrm{ml}$, the amount of water ingested required to cause infection decreases (ibid).

\subsection{Physio-Chemical Parameters}

Again, the contaminated water sources was tested for other essential physicochemical parameters, see table 2 .

Table 2. Physiochemical Characteristics of Water Sources in the Study Area

\begin{tabular}{|c|c|c|c|c|c|c|c|}
\hline Water Sources & pH & TDS & Chlorine & Sulfate & BOD & COD & DO \\
\hline \multicolumn{8}{|l|}{ River Aboabo } \\
\hline S1 & 6.8 & 1005 & 255 & 312 & 6.0 & 8.8 & 4 \\
\hline $\mathrm{S} 2$ & 7.7 & 3568 & 426 & 411 & 14.7 & 115 & 5 \\
\hline \multicolumn{8}{|l|}{ Well water } \\
\hline S 1 & 8.1 & 1234 & 261 & 315 & 10.6 & 45 & 20 \\
\hline S2 & 7.6 & 850 & 246 & 296 & 4.2 & 8.0 & 12.1 \\
\hline WHO Guideline Value & $6.5-8.0$ & $600-1000 \mathrm{mg} / \mathrm{l}$ & $250 \mathrm{mg} / 1$ & $300 \mathrm{mg} / 1$ & $0.8-5 \mathrm{mg} / \mathrm{l}$ & $<10 \mathrm{mg} / 1$ & $7-14 \mathrm{mg} / 1$ \\
\hline
\end{tabular}


Table 3. Trace Metals Composition

\begin{tabular}{|c|c|c|c|c|c|}
\hline Water Sources & Lead & Nickel & Copper & Cadmium & Chromium \\
\hline \multicolumn{6}{|l|}{ R. Aboabo } \\
\hline S1 & 1.2 & 0.026 & 4.96 & 0.014 & 0.070 \\
\hline S2 & 0.15 & 0.018 & 2.11 & 0.012 & 0.052 \\
\hline \multicolumn{6}{|l|}{ Well water } \\
\hline S1 & 0.13 & 0.018 & 1.20 & 0.010 & - \\
\hline S2 & 0.011 & 0.014 & 1.41 & 0.002 & - \\
\hline WHO Guideline Value mg/l & 0.010 & 0.020 & 2.00 & 0.003 & 0.050 \\
\hline
\end{tabular}

S 1(Upstream-Cinema)

S 2 (Downstream-Alonga Junction)

Well 1(Near Aboabo Mosque)

Well 2(Near WEAC)

The analyses of physicochemical properties were determined based on World Health Organization standard methods for the examination of water quality. $\mathrm{p}^{\mathrm{H}}$ is one of the most important tests in water chemistry. It is used to express the intensity of acid or alkaline condition of water. On the scale, $p^{\mathrm{H}}$ ranges from $0-14 ; \mathrm{p}^{\mathrm{H}}$ value of 7 is neutral, $\mathrm{p}^{\mathrm{H}}<7$ is acidic and $\mathrm{p}^{\mathrm{H}}>7$ is alkaline. In chlorinated supplies, $\mathrm{p}^{\mathrm{H}}$ is important as this affects disinfection effectiveness (Schotter, 2008). The differences in $p^{\mathrm{H}}$ between groundwater (Wells) and surface water (streams) may be due to the influence of aquifer materials on the chemistry of the ground water. This is due to the fact that the presence of sulphides and carbonaceous matter in the ore formations means that natural geochemical and biochemical degradation (oxidation) of these rocks may occur, when in contact with oxygen gas containing water, leading to increased hydrogen ion activity in the waters with which they are in contact (WHO 2008). The results further indicate that all the sample sites had $\mathrm{p}^{\mathrm{H}}$ values that were within the WHO limit of $6.5-8 \mathrm{mg} / \mathrm{l}$. The generally low Dissolved Oxygen (DO) content indicated the possibility of increased bacterial activity. Furthermore, high values of BOD and COD at the sampling sites indicate that the water had a low potential to support aquatic life such as fish (ibid). Again, Guideline for TDS was also exceeded at all sampling stations giving an indication that the water bodies are heavily polluted. This could be attributed to groundwater and surface water ingress from the environment that promote volatilization of pollutants from active decomposition of waste mass in to leachate emanating from the disposal site to the nearby ground water source.

\subsection{Trace Metals Composition}

Similarly, five pollutants considered by the WHO to have the greatest potential impact on human health based on environmental persistence, bioaccumulation and amount emitted and/or on inherent toxicity were also considered in the test for water quality. These were Lead Nickel, Copper cadmium and chromium.

The concentration of lead $(\mathrm{Pb})$ in the water samples was above the WHO standards of $0.010 \mathrm{mg} / \mathrm{l}$. This could also be attributed to the presence of commercial activities in the surrounding environment. The high mean concentrations of lead in water samples could have dire implications human health and well being. For nickel, water samples collected from River Aboabo exhibited high values than water samples collected from wells. However, both values greatly exceeded the WHO acceptable exposure level of $0.020 \mathrm{mg} / 1$ Mean concentrations of cadmium $(\mathrm{Cd})$ in the water samples were also higher than the WHO recommended standard of $0.0003 \mathrm{mg} / \mathrm{l}$. Cadmium is considered to be one of most toxic heavy metals and one of the most toxicologically problematic metals in the freshwater environment (WHO, 2005). Cadmium (Cd), even at very low concentrations, can also disturb central functions of human beings by affecting various basic biochemical and physiological processes (Vrijheid., 2000). It enters the environment from natural and anthropogenic sources. $\mathrm{Cd}$ dissolved and constitutes a contamination source for the various aquatic food chain links (Romeo and GnassiaBarelli, 1995). Higher concentrations of copper $(\mathrm{Cu})$ were found in both River Aboabo and the well waters. Mean chromium $(\mathrm{Cr})$ concentrations were slightly above critical standard water levels, hence could not have a major negative impact on the environment.

The high concentration of the trace elements poses a major challenge to the health and well being of the residents. These trace elements have several potentially significant public health challenges that require urgent attention. This is because there is sufficient evidence from human epidemiologic studies linking increased mortality from liver, kidney, bladder, and lung cancers to drinking water contaminated with trace metals (WHO, 2004).

Peoples' perception of water quality has direct implications on their behaviour. The colour and taste of water are important to consumers. The research revealed that 74. 3 per cent of households perceived water contamination as a problem. These were households who used River Aboabo and Well water as their alternative sources. 3 per cent of the respondents said the water quality was good and 21.7 per cent regarded the water quality as 
fair, whilst 1 per cent was indifferent. Perhaps perceptions of quality water were related to the source of water supply. The practice of treating water by boiling or filtering before drinking was completely absent, even not among the households who complained of water contamination. Households did not treat water because of the lack of real acceptance of the role of water in disease causation and unwillingness to commit resources to purchase materials for water treatment, particularly filtering. In addition, there was the popular view that boiling of water was timeconsuming and produces "flat taste".

\subsection{Health Implications}

The extent of water pollution as indicated in the research had profound implications on the health of community members. Inadequate potable water in some cases resulted in higher incidence of self reported cases of diarrhoea and other water borne diseases. As indicated in figure 2, the prevalence of diarrhoea in the community was linked to the source of water supply.

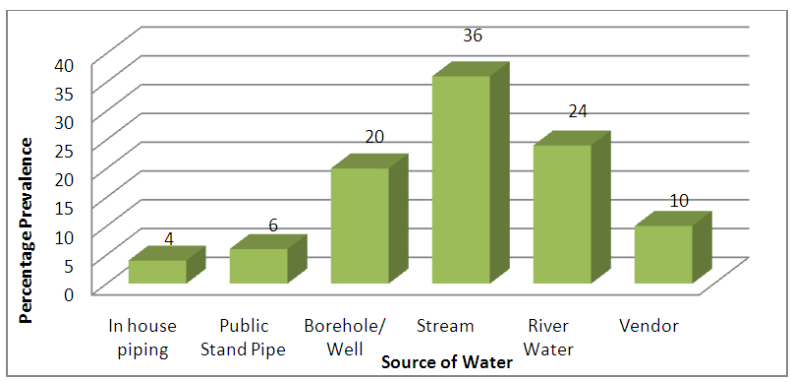

Figure 2. Relationships between Household Source of Water and Diarhoea

The potential health impact of water was the most commonly mentioned concerns in the focus group discussions. "I really have a lot of concerns about the way our water bodies are polluted because of the location of the unsanitary environment.I believe it is the reason why people in this community easily have Diarrhea", a forty year old discussant.

Another community member also observed: "I have concerns about our Well water and not knowing what is going into the ground and what we drink." Residents were specifically concerned about contamination of River Aboabo and the second Well which are located in close proximity to the dumpsite. As one resident stated, "I don't understand how they could put a refuse dump so close to this river. It's very close to it. There's no way that the waste will not contaminate the water and when we drink, we may fall sick and may even die." This view was shared by other community members.

Water borne illnesses are diseases usually either infectious or toxic in nature, caused by agents that enter the body through the ingestion (WHO, 2004). Water poisoning occurs when water is contaminated with germs, or the toxins they produce, and is a leading cause of diarrhea and stomach cramps. Contamination of water with pathogens has been recognized in the leading cause of diarrhea in young children (Cornish et al, 2000).

Globally, the incidence of water borne disease is difficult to estimate, but the World Health Organization indicates that a greater proportion of deaths from diseases can be attributed to contamination of water through improper handling (WHO, 2004). The high prevalence of diarrhea diseases in developing countries suggests major underlying water safety problems. Also, given the overwhelming incidence of improper water handling in the Aboabo community, as outlined above, one will not be wrong to conclude that households in the community are at high risk of water borne diseases. While most water borne diseases are sporadic and often not reported, water borne disease outbreaks may take on massive proportions (WHO, 2005). The pollution of the water bodies leads to the breeding of vectors which may transmit varied water related diseases such as typhoid, cholera, amoebic dysentery and diarrhea. Children are mostly vulnerable to water related diseases because they play regularly in the polluted river and this involves direct body contact and ingestion when swimming in the river.

\subsection{Water Quality Index}

Water quality index (WQI) was used to assess the quality of the water sources relative to the standard for domestic use and to provide insight into the degree to which water quality is affected by human activity. Using the WQI calculator 1.0 (CCME, 2001), the WQI for the Aboabo river was calculated to be 39.3. The WQI indicates that quality of water in the Aboabo river was poor. This implies that the water quality is almost always threatened or impaired; conditions usually depart from natural or desirable levels.

Table 4. Classification of water quality

\begin{tabular}{lc}
\hline Class & WQI Range \\
\hline Ecellent & $95-100$ \\
Good & $80-94$ \\
Fair & $65-79$ \\
Marginal & $45-64$ \\
Poor & $0-44$ \\
\hline
\end{tabular}

Source: CCME, 2001

\section{Conclusion}

Increase in population growth in urban areas has placed an enormous load on the city's water supply system.

Portable water supply endures as an increasingly burdensome challenge for residents and authorities in the KMA. The trajectory of this condition has by now been well-mapped: the scale of urbanization and population growth (from both migration and natural population 
increase) and its resultant increases in demand for water has necessitated the demand for an improved level of water supply which, more often than not, is inadequately provided by city authorities. The difficulty in providing a level of service commensurate with demand is typically due to institutional, technical and financial constraints at national and local government levels and this is well articulated in literature.

The importance of the study is its illumination of issues underpinning how unbridled and unprecedented rate of urbanization has exacerbate the distribution of portable water in a low income community (Aboabo) that has compelled residents to engage in practices that make them vulnerable to water borne diseases. Our findings indicate that an appreciable number of residents rely on water sources whose quality falls below the standard required of portable drinking water.

The expression of water quality entails how the water resources is devoid of and thus clean from any foreign or external elements that could compromise its physical, chemical or bacteriological compositions. High quantities of these parameters in water were present in the Well water and River Aboabo. The fear of utilization of such contaminated waters created 'artificial' shortage or water scarcity in the study area, even though the area is endowed with water resources.

The study revealed that although some attempts have been made to upgrade the community including the expansion of water supply services, little success story can be told. This is attributed to the fact that such policies and program lack local participation and initiatives. The paper is of the view that future policy interventions should actively involve the full participation of the community members if any achievements are to be made. The city authorities need to put in strategies that articulate a shared determination to promote initiatives, plans and policies which encourage pro-poor inclusiveness. Additionally, intense and sustained education on proper environmental management should be the starting point of such policy intervention.

\section{References}

[1] Bacho, Z.L. (2001). From a gift of nature to an economic good: Changing perceptions and management of drinking water. Spring Research series: pp23-44

[2] Birkmann, J. (2006). Measuring vulnerability to promote disaster-resilient societies: Conceptual frameworks and definitions. In Measuring Vulnerability to Natural Hazards-Towards Disaster Resilient Societies; Birkmann. J., Ed.; United Nations University Press: Tokyo, Japan,; pp. $9-54$

[3] Boardi, K. O. and Markku, K. (2005). Environmental and Health Impacts of Household Solid Waste Handling and Disposal Practices in the Third World Cities: The Case of Accra Metropolitan Area, Ghana. Journal of Environmental Health, Vol. 68, No. 4, pp. 34-36.
[4] Canadian Council of Ministers of the Environment (CCME) (2001). Canadian Water Quality Guidelines for the Protection of Aquatic Life: CCME Water Quality Index 1.0. CCME, Winnipeg.

[5] Charbeneau, R. J. (2000). Groundwater Hydraulics and Pollutant Transport. Prentice Hall Inc

[6] Cornish GA, Mensah E, Ghesquire P (1999). Water quality and peri-urban irrigation: An assessment of surface water quality for irrigation and its implications for human health in the peri-urban zone of Kumasi, Ghana. Report OD/TN 95, HR Wallingford, UK.

[7] Daily Graphic. (2013). "Water is Life and Death issue at Sang”. December, 23 edition.

[8] Danquah L, Abass K, Nikoi AA (2011). Anthropogenic Pollution of Inland Waters: the Case of the Aboabo River in Kumasi, Ghana. December. J. Sustain. Dev. 4:6.

[9] Eakin, H., Tompkins, E.L., Nelson, D.R., Anderies, J.M. (2009). Hidden costs and disparate uncertainties: Trade-offs in approaches to climate policy. In Adapting to Climate Change: Thresholds, Values, Governance; Adger, W.N., Lorenzoni, I., O'Brien, K.L., Eds.; Cambridge University Press:Cambridge, UK,; pp. 212-226

[10] Füssel, H.M., Klein, R.J.T. (2006).Climate change vulnerability assessments: An evolution of conceptual thinking. Climatic Change, 75, 301-329.

[11] Giupponi, et.,al (2012.). Climate Change Adaptation and Vulnerability Assessment of Water Resources Systems in Developing Countries: A Generalized Framework and a Feasibility Study in Bangladesh

[12] GWCL (Ghana Water Company Limited) (2011). National Water Policy. Accra, Ministry of Water Resources, Works and Housing:pp56-63.

[13] Hamouda, M.A., Nour El-Din, M.M., Moursy, F.I. (2009). Vulnerability assessment of water resources system in the Eastern Nile Basin. Water Resour. Manag., 23, 2697-2725.

[14] Kanton I. O., Abdul-Rahim L Songsore J, Farouk R. B \& Mulenga M. (2010). Urban water and sanitation in Ghana: How local action is making a difference: pp 1-3

[15] KMA (Kumasi Metropolitan Assembly Waste Management Department) (2010). Data for purposes of planning waste management intervention programmes, Kumasi Waste Management Department. Kumasi, Ghana.:pp 56-71

[16] McGranahan, G (2007), "Urban transitions and the spatial displacement of environmental burdens", in P J Marcotullio and G McGranahan (editors), Scaling Urban environmental Challenges: From Local to Global and Back, Earthscan with UNU-IAS and IIED, UK, pages 18-44.

[17] McGranahan, G., Songsore, J. and Kjellen, M. (1996). Sustainability, Poverty and Urban Environment Transitions. Sustainability, the Environment and Urbanization, London: Earthscan, pp. $21-43$.

[18] McGregor, D. F. M., Thompson D. A. and Simon D. (2000). Water Quality andManagement in Peri-Urban Kumasi, Ghana. In: Land - Water Linkages in Rural Watersheds Electronic Workshop. FAO, Rome September 18- October 27,2000 
[19] Mehrdadi W.N. Wachira, E.G., Omol, R.T.A. and Rakwar, J. (2006). Diarrhoea prevalence and risk factors in slums. $J$. Nat. Inst. Public Health 51, 73-76.

[20] Mercer, J. (2010). Disaster risk reduction or climate change adaptation: Are we reinventing the wheel? J. Int. Dev., 22, $247-264$.

[21] Mwangi, S. W. (2002). Challenges of Urban Environmental Governance, "Participation and Partnerships in Nakuru Municipality, Kenya”, PhD Thesis report,ISBN: 90-7673607-3, Amsterdam, July 2002, pp 30-43

[22] Omane, O.K. (2002). Peri-urban water quality monitoring in the Sisa-Oda catchment of Kumasi (Unpublished master"s thesis). Kwame Nkrumah University of Science and Technology, Kumasi, Ghana.

[23] Parry, M.L., Canziani, O.F., Palutikof, J.P. (2007). Cambridge University Press: Cambridge, UK,;pp. 7-22.

[24] Peters, N. E., Meybeck, M. (2000).Water Quality Degradation Effects on Freshwater Availability: Impacts of Human Activities". Water Int. 25(2):185-193.

[25] Pinderhughes, R. (2004). Alternative Urban Futures: Planning for Sustainable Development in Cities throughout the World. Rowman and Littlefield Publishers Inc. New York. Oxford, Toronto and Lanhaun

[26] Romeo, G. and Gnassia-Barelli, O. (1995). Determinants of women's employment in urban Nigeria: the impact of socioeconomic factors. J. Asian Afr. Studies 34, 279-97.

[27] Saleh, J.A. (2002). Assessement of a Pilot Franchised Solid Waste Collection Scheme in Kumasi. Kumasi: KwameNkrumah University of Science and Technology

[28] Schotter, J. (2008). Epidemiological aspects of leptospirosis in a slum area in the city of Rio de Janeiro, Brazil. Search for leptospires and specific antibodies in rodents. Transactions of the Royal Society of Tropical Medicine and Hygiene 82: 768-770

[29] Simonovic, S.P. (2012). Water Resources Management: A System View.

[30] Torry, W.I. (1978). Bureaucracy, community, and natural disasters. Hum. Organ., 37, 302-308.

[31] Tsiboe, I.A. (2004). A Look at UrbanWaste Disposal Problem in Accra. Roskildem University. Unpublished.

[32] Turner, B.L.; Kasperson, R.E.; Matsone, P.A.; McCarthy, J.J (2003). A framework for vulnerabilityanalysis in sustainability science. Proc. Natl. Acad. Sci. USA, 100, 8074-8079.
[33] Udom, D.J., Ledinghan, J.G.G., and Warrell, D.A., (2002). Oxford Textbook of Medicine. Oxford, U.K. Oxford Medical Publications.

[34] UN/ISDR (2004). Living With Risk-A Global Review of Disaster Reduction Initiatives; UN/ISDR: Geneva, Switzerland

[35] UNESCO. (2009). Water in a Changing World; The United Nations World Water Development Report 3, World Water Assessment Programme (WWAP); UNESCO Publishing: Paris, France; Earthscan: London, UK,

[36] UNFPA. (2001). State of World Population 2004 - the Cairo Consensus at Ten: Population, Reproductive Health and the Global Effort to End Poverty. New York: United Nations Population Fund (UNFPA

[37] UN-Water. (2008). Status Report on Integrated Water Resources Management and Water EfficiencyPlans for the 16th session of the Commission on Sustainable Development; UN-Water: New York, NY, USA,.

[38] USEPA. (1992). Community water and wastewater treatment. Office of research and development, Washington, DC, USEPA, 5-38

[39] Vörösmarty, C.J., Green, P., Salisbury, J., Lammers, R.B. (2000).Global water resources: Vulnerability from climate change and population growth. Science, 289, 284-288.

[40] Vrijheid, M.(2000). Health effects of residents near hazardous waste landfill site: A review of epidemiological literature, Env. Health Perspective: 101-112

[41] WHO. (2004). Guidelines for Drinking Water Quality, Vol 1: Recommendations, 3 edn, Geneva: World Health Organization.

[42] WHO. (2005). Water Supply and Sanitation Collaborative Council and. Sanitation and Hygiene Promotion Guide. Switzerland

[43] Wisner, B., Blaikie, P., Cannon, T., Davis, I. (2004). At Risk: Natural Hazards, People's Vulnerability, and Disasters, 2nd ed.; Routledge: London, UK

[44] Water Resources Commission (WRC) (2003). Ghana Raw Water Criteria and Guidelines, Vol. 1. Domestic Water. CSIR-Water Research Institute, Accra, Ghana.

[45] World Health Organisation (WHO), (2008), Freshwater. (Retrieved July 25 2010) from http://www.unep.org/geo2000/english/0067.htm 